\title{
Titanitis y perititanitis
}

\author{
Titanitis and perititanitis
}

\section{Sr. Director:}

\section{Introducción}

A día de hoy, creemos que podríamos decir y escribir titanitis y perititanitis (términos inventados por nosotros), con los mismos derechos, que Levignac J en Rev Fr Odontoestomatol, 1965 Oct;12(8):1251-60. French, menciona para nosotros algo parecido, en su trabajo "Periimplantation osteolysis-periimplantosis - peri .........." y en el XII Congreso Nacional de Cirugía Oral y Maxilofacial de la SECOM celebrado en Granada del 23 al 25 de junio de 1993, en un Curso Precongreso, que trataba sobre implantología, que fué donde por primera vez escuchamos los términos que por nuestra parte no vamos a escribir $(. \ldots \ldots \ldots y . \ldots$. ........ y y que están muy introducidos en Conferencias, Cursos y escritos en Libros y Revistas Nacionales e Internacionales de gran impacto y actualidad e incluso alguno de ellos en Diccionarios (2). Desde entonces, nos produjo la sensación de que se habían introducido de manera incomprensible en el arsenal y argot científico, como ya denunciamos el mismo día de autos. Nosotros, difícilmente escribiremos esos términos, ¡hasta la fecha no lo hemos hecho! y esperamos que nunca suceda, ya que si así fuera sería como desprendernos y romper con nuestra formación más básica y elemental.

\section{Material y método}

Para este trabajo hemos utilizado y revisado exclusivamente Libros y Revistas, que tratan sobre implantología y que por acuñar los términos, no vamos a poner en la bibliografía, creo que como justo castigo y temas afines de autores de solvencia científica difícilmente cuestionable, pero que como se dice hoy día, nos parece que se han dejado "meter un gol". El método que hemos empleado, no ha podido ser como se comprenderá más simple, sólo hemos tenido que ordenar y recopilar trabajos que aceptan los términos, que algunos tratan de definir e incluso se atreven a clasificar, pero que nosotros, ni siquiera vamos a referir como decíamos, ya que cualquier definición venga de quien venga, precedida de los términos aludidos subliminalmente en éste artículo, resultarían "per

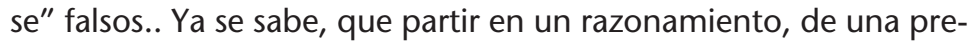
misa falsa, hace que cualquier intento de definición, resulte erróneo y de consecuencias insospechadas. Bastante poco exacta es la medicina, para emplear términos inadecuados como los que son objeto de éste artículo. No hemos encontrado los términos, en el

\section{Dear Director:}

\section{Introduction}

We would like to make some comments about the terms "Periimplantation osteolysis- periimplatosis- peri..... ...., TITANITIS AND PERITITANITIS"

Nowadays, we believe we could say and write "titanitis" and "perititanitis" with the same rights as Levignac J in the French magazine . . . . . . . . . . . . . Odontoestomatol, 1965 Oct;12(8):1251-60. French mentions the terms in his work "Periimplantation osteolysis- periimplatosis- peri . . . . . . . . . . . . ." And in the $12^{\text {th }}$ National Congress of maxilofacial and oral surgery held in Granada from 23rd to 25th June 1993. In a course previous to the congress, which dealt with implantology, and where we heard the terms for the first time; terms that we are not going to write here and are widely introduced in Conferences, courses, books, national and international journals of great impact and modernity, and even some of the terms can be found in dictionaries. ${ }^{2}$ Since then we had the feeling that they had been introduced in a way that was difficult to understand in the medical jargon, as we denounced the same day of the hearing. We are extremely reluctant to use those terms. We haven't done it so far. And hope it will never happen. It would be like betraying our most basic principles.

For this project we have used and revised books and magazines, exclusively dealing with implantology and that won't be cited in the bibliography for having used the terms. Even reputed authors that cannot be questioned by any means have not avoided this pitfall. The methodology we have used cannot be simpler, We just had to gather and order articles that accept the terms, that some try to define and even dare to classify but that we are not even going to refer to since any definition from any person, preceeded by the aforementioned subliminal terms in this article, would result "per se" false. It is known that parting from a thought, from a false pretense, makes any attempt at a definition result incorrect and of suspicious consequences. Medicine is already quite inexact to be using inadequate terms like those described in this article. We have not found these terms in the Dictionary of the Real Academia de la Lengua Española, ${ }^{1}$ but have in some Medical Dictionaries, ${ }^{2}$ although the shortest was not found in neither. They were neither found in book of Pathologic Anatomy consulted and 
Diccionario de la Real Academia de la Lengua Española, ${ }^{1}$ si en algunos Diccionarios de terminología médica, ${ }^{2}$ aunque el más corto, en ninguno de los dos, ni en libros de Anatomía Patológica consultados y cuando fuimos a hablar con los anatomopatólogos del Hospital Universitario Miguel Servet de Zaragoza, sobre los términos, yo ví y sentí, que la cara se les estremecía y eso, que no sabían lo que yo pensaba de los mismos. Vengo poniendo, como enseñanza desde hace años, cuando trato sobre el tema, un ejemplo, ¿si la instalación de un marcapasos conllevara un proceso de infección o intolerancia en el bolsillo subcutáneo creado para su ubicación en los días o meses siguientes a su instalación, quizá se podría hablar de perimarcapasitis?, o quizá no... ¿verdad?, pues lo mismo digo de la ......... y de la ............ (rellénese por el lector cada punto, con las letras correspondientes) y quizá sepan si todavía no se han dado cuenta, cuales son los términos a olvidar.

\section{Conclusiones}

Seguro que los términos que proponemos en el título de nuestro artículo, son inadecuados y no deberían permanecer en el ambiente científico hablado ni escrito, ni en el del día a día, en el ámbito de la implantología, así como tampoco los términos ya establecidos que criticamos y eludimos y que un vez mas dejamos insinuados con puntos correspondientes a cada letra de los términos a olvidar y que el lector, seguro que es capaz de identificar, una vez más, poniendo cada letra como apuntábamos, encima de cada respectivo punto $(\ldots \ldots \ldots . . . . \ldots \ldots \ldots . .$. . efectivamente.. ésos son los anómalos términos, a los que nos referimos- y si así no ocurriera, reivindicamos, creo que con todos los derechos, los de titanitis y perititanitis, no faltaría más., ya puestos a desbarrar científicamente...

Por supuesto, que no nos atrevemos a sustituir los desafortunados términos por unos concretos, sin tener a nuestro lado un equipo científico idóneo y multidisciplinar, aunque ya los hay en uso prácticamente y bastaría recuperarlos, para poder escribir y hablar de los fenómenos que pueden producirse en la periferia de los implantes de titanio instalados en hueso vivo tanto en los arropados con fibromucosa o con determinados injertos, lubricados con saliva y en contacto con la flora y temperatura bucal o bien con piel y en ambiente seco, como ocurre en los extraorales y también los sumergidos, en éstos casos, sin relación con el exterior y que serían los que verdaderamente soportarían un ambiente mas aséptico, como los que se emplean para reconstrucciones de pequeñas y grandes articulaciones, todo ello, sin apartarnos de lo que debería ser el lenguaje y la nomenclatura científica tanto médica como veterinaria y siempre individualizándolo según el medio donde esté instalado el implante.

Los metales sufren procesos de oxidación por diversos motivos y ambientes, unos son más sensibles que otros, los más resistentes al proceso serían los metales nobles, oro, platino, plata, etc., pero quizá no estemos autorizados a identificar dichos procesos, como fenómenos inflamatorios semejantes o parecidos a los fenómenos que ocurren en los tejidos orgánicos vivos.

Para quienes trabajamos con implantes y pretendemos explicar when we went to speak with anatamopathologists at the Miguel Servet University Hospital in Zaragoza about the terms, I felt and saw that there faces became distorted, and all this without them nothing what I thought. I put, as a form of education since a couple of years ago, when I speak on the subject an example: If the placement of a pacemaker would requiere a process of infection or intolerance in the subcutaneaos pocket created for its location in the days following its placement, maybe we could speak about a peripacemakeritis? Or maybe not, no? Well I speak the same of the ............ and the . ........... ( fill in by the reader, with the corresponding letters., then maybe you can discover the terms that you should forget.

\section{Conclusion}

In conclusion, I'm sure that the terms we propose in the title of our article are inadequate and should not remain in the scientific environment, either spoken or written, nor in our day to day. Just as established terms. If this does not occur, we would proclaim, I think with all rights, those of titanitis and perititanitis.

Of course we do not dare to substitute these unfortunate terms for other concrete ones without having a specific and multidisciplinary scientific team on our side; although they are already in practical use and can be easily recovered to be able to write and talk of the phenomenons that can take place in the perifery of titanium implants installed in live bone both in those covered in fibremucus or with determined skin grafts lubricated with saliva and in contact with the flora and the buccal temperature or with the skin in a dry environment. This may occur in the extraoral and sumergible cases with any relation with the exterior and would be those who truly support a more asceptic environment, like those used to reconstruct small and large articulations, all this without departing of what should be the scientific nomenclature and language both in the medical and veterinary world and always individualized by the medium where the implant is installed.

Metals suffer from oxidation for various reasons and environments, some more sentive than others. Those most resistant to the process would be the noble metals such as gold, platinum, silver, etc., but perhaps we are not authourized to identify such processes as inflamatory phenomenons similar or alike to those that occur in organic tissues.

For those of us who work with implants and try to explain the diverse phenomenons that can occur, both positive and negative for the organisms that support them; it is essential to have the capacity of abstraction neccesary to interpret them outside the context of the speciality in which they are applied and value them with wider perspectives and always inside the canons of a serious investigation, impartial and accustomed to linguistic mimicry, 
los diversos fenómenos que pueden presentarse, tanto positivos como negativos para el organismo que los soportan, es esencial tener la capacidad de abstracción necesaria par interpretarlos fuera del contexto de la especialidad a las que se aplican y valorarlos, con miras más amplias y siempre dentro de los cánones de una investigación seria, no partidista y acostumbrada a mimetismos linguísticos, como les ocurre a determinados grupos que los utilizan más frecuentemente que otros, como sucede por desgracia, en el ambiente de la cirugía oral y maxilofacial, estomatología y odontología. No es lo mismo odontitis (término que tampoco he encontrado) o periodontitis que :......... (11 puntos) y ....... ...... (15 puntos), ya saben el qué, y por favor no los empleen en el argot científico en ninguna de sus modalidades.

\section{Prof. Dr. D. F. Hernández Altemir}

Colaborador Extraordinario de la Universidad de Zaragoza. Facultad de Ciencias de la Salud y del Deporte. Licenciatura de Odontología, Zaragoza, España

Susana Hernández Montero Médico Odontólogo (Endodoncia) Práctica privada Sofía Hernández Montero Médico Especialista de Odontología y Cirugía Oral y MaxilofacialProfesora de la Universidad Alfonso X el Sabio de Madrid y Directora del Master de Implantología, Madrid, España

Elena Hernández Montero

Medico Especialista en ORL en el Hospital de Viladecans y del Instituto García-Ibáñez de Otoneurología, Barcelona, España like those that occur to determined groups that use them more frequently than others, which occurs unfortunately in the environment of oral and maxilofacial, stomatology and odontology surgery. It is not the same to say odontitis (term I have not found either) or periodontitis than...... you know what.

\section{Bibliografía}

1. Diccionario de la lengua española (Vigésima segunda edición)- 2001.

2. Dorland: Diccionario Enciclopédica llustrado de Medicina 30. ${ }^{\text {a Edición. }}$

3. Más de 100 años de Historia. 